University of Nebraska - Lincoln

DigitalCommons@University of Nebraska - Lincoln

Publications from USDA-ARS / UNL Faculty

U.S. Department of Agriculture: Agricultural

Research Service, Lincoln, Nebraska

2008

General Introduction to Areawide Pest Management

Robert M. Faust

USDA-Agricultural Research Service

Follow this and additional works at: https://digitalcommons.unl.edu/usdaarsfacpub

Part of the Agricultural Science Commons

Faust, Robert M., "General Introduction to Areawide Pest Management" (2008). Publications from USDAARS / UNL Faculty. 645.

https://digitalcommons.unl.edu/usdaarsfacpub/645

This Article is brought to you for free and open access by the U.S. Department of Agriculture: Agricultural Research Service, Lincoln, Nebraska at DigitalCommons@University of Nebraska - Lincoln. It has been accepted for inclusion in Publications from USDA-ARS / UNL Faculty by an authorized administrator of DigitalCommons@University of Nebraska - Lincoln. 


\title{
General Introduction to Areawide Pest Management
}

\author{
ROBERT M. FAUST \\ USDA-Agricultural Research Service, Beltsville, Maryland, USA
}

\begin{abstract}
Welcome to the realm of areawide pest management (AWPM). This book represents one of the first comprehensive 'treatises' on the AWPM concept and approach, and should be of interest and use to many types of readers, from research scientists in government, university and industry to pest control advisors and extension personnel, growers, pest control and integrated pest management (IPM) practitioners, students, teachers, natural resource managers and others interested in environmentally sound pest control. There is a range of topics included in the subject area. The book is grouped into three parts. Chapters 2-8 discuss the foundation of areawide pest management; Chapters 9-20 describe case examples of recent areawide pest management programmes and projects; and Chapter 21 is a synthesis of the book's contents that integrates the theory and concepts presented in the various chapters into common themes that arise from the case examples. Chapter 21 also contains a discussion on the future potential of the areawide approach and how it augments and expands upon the traditional IPM strategy.

Historically, the AWPM concept in some form or another has been practised since the late $1800 \mathrm{~s}$. The overall premise is that a number of serious economic pests can be effectively managed using an organized and coordinated attack on their populations over large areas rather than by using a field-by-field approach (Knipling, 1978, 1979; Rabb, 1978; Knipling and Stadelbacker, 1983; Bellows, 1987; Myers et al., 1998). The entomological literature contains numerous examples of large-scale, highly coordinated programmes that fit into the areawide concept. Chandler and Faust (1998) have given a number of historic examples of AWPM programmes in a previous publication, and they will be highlighted here only for the purpose of this introduction, with a few additional examples added. The reader is referred to the publication by Chandler and Faust (1998), as well as to the various chapters in this book, for more detailed historic information.

Very early programmes targeting a key pest over a wide area are mentioned in the scientific literature. One programme was against the grape phylloxera, Daktulosphaira ritifoliae, in Europe during the 1870s and 1880s, using resistant grapevines (Kogan, 1982).
\end{abstract}


The pest was fully under control by 1890 . Classical biological control was used for the cottony cushion scale, Icerya purchasi, a pest that seriously affected the California citrus industry in the 1880s. Two biological control agents were introduced from Australia, the vedalia ladybeetle, Rodolia cardinalis, and the parasitic fly, Cryptochaetum iceryae. The vedalia ladybeetle brought about the complete suppression of this scale insect by the end of 1889 (Doutt, 1958), and this has been attributed to an AWPM strategy that used coordinated efforts and a broad distribution of the two biological control agents.

Several eradication programmes have been highly successful using areawide concepts as an integral part of the programme, with the goal of bringing the populations down to zero: those for the cattle ticks, Boophilus annulatus and Boophilus annulatus var. microplus, and the screwworm, Cochliomyia hominovorax. The two species of cattle tick had been eradicated from most of the USA by the 1950s (Cole and MacKeller, 1956) via a cooperative federal and state cattle-dipping protocol commencing in 1906 across 15 southern and south-western states. Using a sterile male technique, the screwworm was eradicated from the USA, Mexico and portions of Central America (Knipling, 1979; Bushland, 1985; Baumhover, 2002). Since 1991, the screwworm also has been eliminated from Belize (1994), Guatemala (1994), El Salvador (1995) and Honduras (1995) (USDA-APHIS, 1998).

The sterile male tactic has also been used to eradicate the melon fruit fly from Okinawa and the southern islands of Japan, as well as against the tsetse fly on the island of Unguja, Zanzibar (Vreysen et al., 2000). The US Animal and Plant Health Inspection Service (APHIS) also uses the sterile male technique to eradicate recurring infestations of the Mediterranean fruit fly from the continental USA, in partnership with the affected state(s). A number of other AWPM programmes have been in progress throughout the world and will be summarized briefly later in this introduction. The description of AWPM examples, which makes up Chapters 9-20 of this book, provides more detailed information concerning several projects.

There is consensus that the recent interest in AWPM is related to the great success of the screwworm eradication programme, with Dr Edward F. Knipling, US Department of Agriculture (USDA), Agricultural Research Service (ARS), having been a strong proponent of the screwworm effort going back to at least 1955. A more definitive AWPM concept was published by Dr Knipling (Knipling, 1980), referring to it as 'regional management'; this probably helped to lay the theoretical foundation for the concept and the criteria for implementing AWPM projects, and since then the numerous discussions and planning activities around the concept that will be discussed in this introduction have built upon this foundation. Even as early as 1966, Dr Knipling (Knipling, 1966) envisioned the advantages of 'areawide management' as opposed to a 'field-to-field' approach. However, Knipling recognized that not all pests are good candidates for areawide tactics, necessitating reliance on a field-byfield control approach. Klassen (2003) has published a detailed account of Knipling's thoughts and activities in areawide and eradication applications, and the reader is referred to this excellent article for more information.

In September 1992, Knipling and G.G. Rohwer presented a proposal to the North American Plant Protection Organization (NAPPO) entitled 'Area-wide Pest Management' (E.F. Knipling, Maryland, 1993, personal communication). Their vision of the process was that AWPM programmes must be: (i) conducted on large 
geographical areas; (ii) should be coordinated by organizations rather than by individual producers; (iii) may involve eradication, if practical and advantageous, but should focus on reducing and maintaining a pest population at an acceptably low density; and (iv) must involve a mandatory component to ensure project success within the entire geographic area, because 'voluntary programs historically have not provided the desired level of pest management'.

Areawide pest management was defined as the systematic reduction of a target pest(s), to predetermined levels by uniformly applied mandatory pest mitigation measures over geographical areas clearly defined by biologically based criteria (e.g. pest colonization, dispersal potential). 'Pest' as used in the definition can include weeds, pathogens of animals and plants, and insects or other organisms (e.g. mites, ticks) that have an economic impact on the agricultural industry or human health. The stated advantage of managing pests on an areawide basis is that AWPM can offer a long-term solution to agricultural pest problems as opposed to quick-fix solutions on individual crops or small acreage. Properly implemented, the methodology could prevent major pest outbreaks and provide a more permanent control procedure for pests.

Areawide pest management and IPM were seen as similar, distinct and potentially complementary. The two approaches could be complementary in that when a key pest is effectively managed in an areawide programme, the potential to manage other key pests and secondary pests by alternative approaches becomes more readily achievable. Although AWPM generally targets a key pest or small group of pests, the strategy should consider other pests (e.g. secondary pests) in the system in a holistic fashion. On the other hand, IPM is often applied to individual farms or cropping systems and is generally voluntary in nature. As the reader will see throughout the various chapters, the mandatory requirement suggested in the proposal to NAPPO for AWPM programmes has not always been strongly adhered to in some programmes initiated in recent times, but these have been quite successful without such a requirement, given a vigorous outreach effort. The boll weevil eradication programme in the USA is an example of an effective 'mandatory' AWPM programme (Dickerson and Haney, 2001). A caveat here is that a federally implemented boll weevil eradication programme was not seen as the desired option, but that state regulatory authority, combined with USDA support and local grower leadership, provided the preferred option for the programme. Most of the funding support for this programme now comes from the cotton producers within each region.

Integrated pest management generally addresses the complex of pests in a production system and the pest problems associated with multi-commodity production systems intercropped or in crop rotation systems. Close to 70 definitions of IPM have been proposed (Bajwa and Kogan, 2002), with them all sharing a common theme: IPM is a sustainable, environmentally friendly approach to managing pests by combining biological, cultural, physical and chemical tools in a way that minimizes economic, health and environmental risks. This includes anticipating pest problems and preventing pests from reaching economically damaging levels. All appropriate techniques can be used, such as enhancing natural enemies, planting pest-resistant crops, adapting cultural management and using pesticides judiciously. It relies on a combination of common-sense practices.

As practised, IPM can consist of approaches to integrate two or more control techniques to manage one or more species of the same single grouping of pests, such 
as weeds, mites, ticks, insects, nematodes or diseases. It also can consist of approaches to integrate two or more management systems for two or more pest groupings, such as diseases and insects, or diseases, weeds, insects and nematodes.

Benbrook et al. (1996) view IPM systems as occurring along a continuum, which has been categorized into four levels of adoption: (i) no IPM, which corresponds to systems essentially dependent on pesticides and not using basic IPM practices like proper calibration, operation and cleaning of spray equipment, scouting for pests, and sanitation and good agronomic practice; (ii) low-level IPM, where farmers use at least the most basic IPM practices of scouting and application in accord with thresholds, avoiding or delaying resistance and secondary pest problems, optimally timing applications, and some preventive practices, such as short rotations, resistant varieties and cultivation; (iii) medium-level IPM, i.e. systems in which farmers have adopted some preventive measures, coupled with efforts to cut back on broad-spectrum pesticide use, protect beneficial organisms and assure that pesticides are applied most efficiently - includes multi-tactic approaches to limit or remove pest habitat and augment biodiversity, resistant varieties, use of cover crops and longer rotations, enhancing beneficial organisms, use of soil amendments and disease-forecasting models; and (iv) high-level, or multi-strategy biologically intensive IPM, the zone farthest along the IPM continuum, where farmers have integrated multiple preventive practices and, as a result, have become able to control pests without relying routinely on pesticides.

Integrated pest management is site specific in nature, but certain general criteria must be met for control measures to qualify as IPM practices. At a minimum, each site should have in place a management strategy, which includes prevention, avoidance, detection and suppression of pest populations, as envisioned by Dr Harold Coble of North Carolina State University, USA and the USDA IPM committee (Stall, 1999). The more biologically intensive the approach in each of these strategies, the further along the continuum the grower will be. In recent years, AWPM proponents in the USA have begun using the term areawide IPM to more accurately describe programmes currently being conducted. Strategies useful to IPM can likewise be applicable to AWPM as components of its foundation. And, of course, it is desirable that AWPM programmes be as far along the continuum as possible.

Regardless of whether IPM is being used on a farm-to-farm approach or incorporated into an areawide approach within the distinct criteria of AWPM the aim is still to maintain pest populations below damaging levels, based on proper use of the technologies available. AWPM (as does IPM) depends on the availability of adoptable, pest-specific management tools. These tools must control the pest, impact little else in the environment and not form residues on the food product, where they could be a hazard to the health of the consumer. AWPM strategies do not replace IPM concepts, but support IPM and embrace its technologies.

Technologies that can be used, depending on the situation, in AWPM approaches include:

1. Traditional biological control - the use of parasites, parasitoids, predators, pathogens, competitors and other beneficial organisms to reduce the harmful effects of pests, which may embody augmentation and conservation biological control tactics. 
2. Biologically based (biorational) control - the use and application of biologically based methods (e.g. hormones, antimetabolites, feeding deterrents, repellents, pheromone and allelochemicals (semiochemicals) and other naturally produced chemicals, attracticidal compounds, traps and similar devices, autocidal methods/ sterile technology, etc.).

3. Host resistance - the use and application of pest-resistant crop cultivars and animal breeds, including genetically engineered plants and animals resistant to pests.

4. Cultural practices - the use and application of tactics such as crop rotation, intercropping, tillage approaches, cover crops or mulches, managing irrigation and drainage, fertilization, removal of crop residues and other field sanitation procedures, altering planting and harvesting schedules, and related strategies.

5. Physical and mechanical control - the use of physical and mechanical methodology, thereby exerting economic control or reducing rates of pest contamination and damage, e.g. vacuum collection, screening, trapping and other exclusion tactics, etc.

6. Chemical control - the use of broad-spectrum synthetic organic (non-naturally occurring), or analogues of, natural chemicals (e.g. pyrethroids, insect growth regulators, etc.) or inorganic chemicals for controlling animal and plant pests, including fumigation, the use of improved chemical pesticide formulations and improved pesticide application technologies (judicious use is desirable).

Models and expert systems, including predictive types and decision support systems for pest-plant/animal environmental integration, including vector-disease interaction and control agent(s) interaction are important components when available to use in order to facilitate a systems approach to maximizing plant/animal protection and environmental compatibility.

Closely related to these technologies will be an understanding and exploitation of information on the movement and dispersal of pest and beneficial species, timing of population suppression measures to coincide with low pest population densities, and optimal conditions for use of environmentally friendly technologies. The economics of the strategy are vitally important to adoption. It is essential that AWPM programmes be interfaced with multi-pest IPM systems and that systematic approaches are taken in selecting a pest(s) to be targeted for AWPM.

A number of criteria need to be considered as guidelines when implementing AWPM programmes (Kogan, 1995; Chandler and Faust, 1998; Faust and Chandler, 1998), a few of which have been mentioned above. The programme should be defined by some geographic entity that encompasses farms as well as all other non-farm components of the landscape, and should be conducted over large geographical areas with consideration of pest colonization and movement and dispersal of pest and beneficial species. The area should represent typical production settings with representative pest problems and consistent populations of the key pest $(\mathrm{s})$. It is important to have assurance that the target pest $(\mathrm{s})$ is amenable to control using the areawide concept over a large geographical area that may extend across county, state and, in some instances, national boundaries. Consider whether there are environmental factors that change over the area that could affect the programme. An understanding of the pest biology, ecology, genetics, behaviour, physiology, interactions with other organisms and other biological and physical characteristics of the system is critical. Is the pest genetically different in different parts of the area? What are 
the natural control factors? Is there a reasonable isolation of the area from other non-included infested areas such that migration into the target area or region will be minimized during the programme? What are the geographical barriers? Is there a reasonable representation of the host range (including wild relatives of the crop plant in the case of crop AWPM programmes) so that the effects of residual populations can be evaluated? What other pests exist in the ecosystem that could become important as the target/key pest(s) is managed? What are the parameters of the production system and the inputs? Has the technology been proven in smaller-scale tests?

An AWPM programme should be coordinated by groups of key participants as opposed to by just individual producers or other end-users, and the programme should involve federal (as needed), state and local extension, commodity and private grower groups, communities, agribusinesses and other stakeholders in a true partnership. Extension IPM programmes should be in place in the state or region, or planned to be developed in synchrony with the AWPM programme to ensure that multiple pest and secondary pest problems will be managed and the full impact of a combined programme will be realized. Bio-intensive, environmentally sound and economical technology must be available to the end-users and, of course, the programme should focus on reducing and maintaining a pest population at an acceptably low density, providing positive environmental benefits and food and worker safety, with a high benefit:cost ratio. Implementation of AWPM will require overall participation and compliance of growers in the area under the strategy for optimum success, as well as frequent evaluation to measure effectiveness and to assure that goals are being met. The remainder of this book will dwell in more detail on the various considerations raised here when implementing AWPM programmes.

As mentioned previously, a number of AWPM programmes in recent times have been in progress throughout the world. Earlier publications - Chandler and Faust (1998); Faust and Chandler (1998) - of the USDA's Agricultural Research Service summarized many of these programmes, and excerpts from those two publications will be included here, along with some additions to update the various activities using AWPM/IPM strategies. No great detail will be provided in this introduction of the various projects, since many that will be mentioned are already described in some detail later in this book. In any event, the various activities summarized here will serve as an indicator of the current status of AWPM.

Since the 1960s, numerous suppression programmes targeted at the pink bollworm, Pectinophora gossypiella, have been initiated. An areawide management programme for this pest has been in place in the San Joaquin Valley of California, USA, continuously since 1968 (Henneberry and Phillips, 1996). Most of the current pink bollworm suppression programmes that are established or under development use sterile insect releases, cotton plant destruction, mating disruption and trapping for management of the pest. The ongoing cotton boll weevil (Anthonomus grandis) eradication programme, which was initiated in North Carolina, South Carolina and Virginia, USA, in 1977, is another example of a successful, highly coordinated areawide management programme (Henneberry and Phillips, 1996). Suppression methods generally have included insecticides and cultural measures on in-season and overwintering populations, use of grandlure pheromone traps to reduce weevil populations emerging in the spring, and sterile boll weevil releases. 
Cotton farmers in Arkansas, USA, have voluntarily organized bollworm management communities in an attempt to suppress cotton bollworm and tobacco budworm populations areawide rather than by a field-by-field approach (Henneberry and Phillips, 1996). The aim has been to coordinate control decisions so that all cotton fields in a cotton bollworm management community are treated within a 3-day period.

In the USA two other important areawide IPM programmes have been implemented and the technologies transferred by the federal government to the affected states.

These programmes have been targeted at the gypsy moth and grasshoppers, serious pests of trees and rangeland/crops, respectively. The gypsy moth (Lymantria dispar) was introduced into the USA in 1869 and has defoliated thousands of acres of hardwood forests across the north-east, from Maine to North Carolina, infesting 19 states and Washington, DG. (APHIS, 2003). In 1992, the USDA's Forest Service (FS) and APHIS, along with the Department of Interior's National Park Service and eight state and university partners, embarked on a pilot project called 'Slow the Spread'. The project's goal was to slow the rate of natural spread of the gypsy moth by using IPM strategies (APHIS, 2003). In 1999, following successful completion of the pilot project, the National Gypsy Moth Slow the Spread programme was implemented along the entire 1200-mile gypsy moth frontier from North Carolina through the upper peninsula of Michigan. The programme area is located ahead of the advancing front of the gypsy moth population, and concentrates on early detection and suppression of the low-level populations along this advancing front, disrupting the natural progress of population expansion. Suppression tactics have included pheromone mating disruption, mass trapping and treatment with the microbial pesticide, Bacillus thuringiensis (Bt), diflubenzuron (except in Michigan) or a naturally occurring virus (Gypchek). The programme includes a compliance with regulations covering movement of gypsy moth host materials.

Grasshopper population outbreaks in the Great Plains and Intermountain West have occurred for many decades. In response to a grasshopper epidemic in the mid-1980s, APHIS initiated a Grasshopper Integrated Pest Management (GHIPM) Project in 1987 to develop and demonstrate new IPM technologies for transfer as a package to managers of public and private rangelands (USDA-ARS-APHIS-U.WY, 2001). APHIS had been given a congressional mandate to manage these pests on federal rangeland. APHIS had the responsibility to direct a coalition of federal agencies for the GHIPM Project. Agencies included in this project were the USDA's Agricultural Research Service, Economic Research Service, Forest Service and Extension Service (now known as the Cooperative State Research, Education and Extension Service); the US Department of the Interior's Bureau of Land Management, US Fish and Wildlife Service and National Park Service; and the US Environmental Protection Agency's Office of Pesticide Programs. Also, state departments of agriculture, land grant colleges, grazing associations and private industry joined the effort. The GHIPM demonstration project ran from 1987 to 1994 in areas of Idaho and North Dakota. Products of the programme included a Grasshopper Integrated Pest Management User Handbook and a CD (USDA-ARS-APHIS-U.WY, 2001). In addition to the user handbook, the CD also contains a field guide to common western grasshoppers; a section on grasshoppers (Acrididae) of Colorado: identification, biology and management; 
HOPPER 4.0 and CARMA 3.3 decision support software for rangeland grasshopper management; and additional grasshopper management and GHIPM Project descriptions and information. Copies of the Grasshopper IPM User Handbook may be obtained from USDA, APHIS, PPQ, Operational Support Staff at 4700 River Road, Riverdale, Maryland 20737. The CD may be obtained from USDA-ARS Northern Plains Agricultural Research Laboratory, at 1500 North Central Avenue, Sidney, Montana 59270.

In 1993 USDA's Agricultural Research Service, in concert with a USDA IPM Working Group, developed a partnership framework for an AWPM initiative that would include the federal, state and private sectors as partners. On 27 September 1993, key pest management representatives from the USDA, university research and extension and several state Departments of Agriculture participated in an organizational meeting in Beltsville, Maryland. At this meeting, participants identified key pests and cropping systems for which environmentally sound pest management technologies were available for implementation on an areawide basis (Faust and Chandler, 1998). Dr Knipling played a pivotal role in the organizational meeting.

The goals of ARS's AWPM partnership initiative are: (i) to demonstrate technologies that will suppress key target pests to manageable levels using the AWPM IPM concept; (ii) increase community involvement in the initiative through educational programmes during the programme; (iii) increase economic benefits to end-users, the community and other stakeholders as a result of the programme; (iv) promote a sustainable AWPM suppression programme; and (v) introduce, transfer and promote adoption of the demonstrated pest suppression technology.

The USDA-ARS funded AWPM programme and the 5-year panel selected projects typically are structured around four key components: (i) operations (the demonstration sites); (ii) assessment (economic, sociological and environmental impacts); (iii) education (outreach and technology transfer, including training and various communication tools); and (iv) research, the results of which are intended to aid in the improvement of programme efficacy or to help circumvent obstacles to implementation (Faust and Chandler, 1998). None of the projects contains a mandatory requirement, but they do have a highly active outreach component. Extension and county agents sustain the strategies in the out-years.

The first USDA-ARS AWPM demonstration partnership project was implemented in 1994, in the north-western USA against the codling moth, Cydia pomonella (Calkins and Faust, 2003). Mating disruption was used to reduce the pest population while reducing the use of organophosphate insecticides. In 1995 a second project was initiated for corn rootworms (Diabrotica spp.) in the Midwest by using adult semiochemical insecticide bait (Chandler and Faust, 1998; Chandler, 2003). Corn rootworm populations were significantly reduced at participating sites, and new bait products were developed and evaluated for use in rootworm-infested areas. Products produced by several companies have been used in IPM wide area strategies in Hungary, Croatia, Italy and Argentina for corn rootworms (L.D. Chandler, Fort Collins, Colorado, 2006, personal communication). The ARS initiated two other AWPM IPM projects in 1996: one project was directed at insects of stored grain in Kansas and Oklahoma (Flinn et al., 2003). The project used two elevator networks, one in each state, for a total of 28 grain elevators. Stored wheat was followed as it was moved from farm to the country elevator and finally to the terminal elevator, thus giving the 
project an areawide perspective. Fumigation using aluminium phosphide pellets, as needed, along with sampling/monitoring and decision support software, was used in the demonstration project.

The other project was directed at the leafy spurge weed (Euphorbia esula) and was initiated as a partnership between the ARS in Sidney, Montana; the USDA-APHIS; North and South Dakota State Universities; and Montana State University; in cooperation with the Forest Service, Cooperative States Research, Education and Extension Service (CSREES), the Bureau of Land Management, National Park Service and the state Departments of Agriculture (Anderson et al., 2003). This project used biological control with emphasis on a beetle herbivore (Apthona sp.) of leafy spurge, and other technologies such as grazing systems, revegetation, decision aids, geographical information systems (GIS) and judicious use of herbicides, as needed.

Between 1999 and 2006, ARS initiated six additional AWPM demonstration projects, which are ongoing or just being completed, many of which are detailed in the case examples of this book. For example, in 1999 an AWPM IPM project in the Hawaiian Islands for management of tephritid fruit flies using monitoring, sanitation, male annihilation, baits, biological control and sterile male fruit flies was initiated (Mau et al., 2007). The target species included Mediterranean (Ceratitus capitata), melon (Bactrocera dorsalis), oriental (B. dorsalis) and Malaysian fruit flies (B. latifrons). The overall goal is to suppress these pests below economic thresholds. Fruit flies, especially the oriental and Mediterranean, continue to show up in the continental USA, and the technologies being demonstrated in Hawaii are enhancing suppression and eradication programmes of these invasive species in the USA and elsewhere. Already, the programme has led to initiation and adoption of the AWPM tactics in Pacific Basin Areas such as French Polynesia, Fiji, Vanuatu, Guam, Cook Islands and the Northern Mariana Islands, as well as in districts in Taiwan and Queensland, Australia.

Besides the ARS partnership demonstration fruit fly project in Hawaii, a number of AWPM programmes are currently being conducted around the world that target fruit flies, largely using sterile insect techniques. These projects are in Argentina, Australia, Costa Rica, Greece, Guatemala, Mexico, Pakistan, Peru, Philippines, Portugal, Thailand and the continental USA (Hendrichs and Ortiz, 1996). A number of these programmes are coordinated mainly by grower associations and government agencies, and do prevent major economic damage to numerous fruits and vegetables.

In 2000, a project on fire ants (especially the red imported, Solenopsis invicta, across Florida, Mississippi, South Carolina, Texas and Oklahoma) on pastures was initiated using natural enemies (phorid fly parasites), microbial agents and attracticidal compounds (Flores and Core, 2004; Pereira, 2004; Van der Meer et al., 2007).

Then, in 2001, three additional projects were implemented: (i) Russian wheat aphid (Diuraphis noxia) and greenbug (Schizaphis graminum) on wheat in the US Great Plains using customized cultural practices, pest-resistant cultivars, biological control agents and other biologically based pest control technologies (Keenan et al., 2007); (ii) the Melaleuca weed tree (Melaleuca quinquenervia) in Florida using natural enemies and microbial biological control (fungus), judicious use of herbicides, mechanical (mowing) and physical (fire) control, and combinations of these tactics (Flores, 2004a; Scoles et al., 2006); and (iii) the tarnished plant bug (Lygus lineolaris) on cotton in the 
delta of Mississippi and Louisiana using host destruction, host-plant resistance and remote-sensing technology, which was an extension of an ongoing ARS project (Weaver-Missick, 1999; Abel et al., 2007).

In 2006, a project targeted at methyl bromide alternatives in Florida and California was initiated to assess, test and transfer an IPM wide area strategy using methyl bromide alternatives against soil pathogens, nematodes and weed pests for growers who are losing the fumigant (Schneider et al., 2003) because of regulatory action. The ARS plans to continue implementing additional AWPM-IPM demonstration projects in the future as funds are released from ongoing projects being completed. For example, in October 2007 projects targeted at the Asian tiger mosquito, navel orange worm, pests and pathogens of honey bees, and weedy annual grasses of rangelands were initiated.

There have been other ARS wide area IPM projects not directly funded by the ARS AWPM initiative that have been implemented. Since 1992, ARS has led federal and state scientists in a nationally coordinated research effort to develop technologies for mitigation of the silverleaf whitefly (Bemisia argentifolis) problem in ornamental, vegetable, melon and fibre crops across the southern USA, and in greenhouses (De Quattro, 1997; Henneberry et al., 2002). This insect has been responsible for over US $\$ 2$ billion in crop loss, damage and control measures since its introduction into the USA in 1986. Areawide and community-based management approaches, covering all affected commodities, have emerged as the best strategy and have been adopted. Some crop management- and community-oriented farm practices, such as water-use patterns, proximity of alternate host crops and spatial considerations, have been implemented, resulting in whitefly population reduction. An excellent insecticide resistance management programme has been implemented to conserve a major insect growth regulator (imidocloprid) found effective under the programme. A number of other management tools have been developed and adopted by growers, including crop rotation, host-free periods, crop residue and weed destruction, host resistance and biological control (fungi, parasites and predators). Overall losses have not increased in agricultural communities where the silverleaf whitefly is a factor in crop and horticultural production and have declined in a number of cases.

In 1997 USDA-ARS implemented a 5-year wide area project against the blacklegged deer tick (Ixodes scapularis) in the north-east USA (Pound et al., 2000a; McGraw and McBride, 2001). The project uses a device named the 'four-poster' as an alternative to eliminating deer populations or applying chemical sprays. The tick transmits the agent that causes human Lyme disease (Borrelia burgdorfer). The 'fourposter' consists of a bin filled with whole-kernel maize and paint rollers attached to the bin's four corners. An acaricide (amitraz) is applied to the rollers and the acaricide rubs off and kills ticks on the deer's head and neck when the animal feeds between the rollers. ARS scientists in Kerrville, Texas, developed the technology. The technique is also used in Texas against lone star ticks (Amblyomma americanum) (Pound et al., 2000b; Flores, 2006). In 2003 scientists in Scotland began testing the '4-poster' topical applicator in that country (Flores, 2004b).

ARS scientists in New Orleans, Louisiana, USA have recently established an areawide treatment programme (Operation Full Stop) for the Formosan subterranean termite, Coptotermes formosanus. The project uses new termite control technologies that include monitoring/baiting technology and non-repellent termiticides 
(Lax and Osbrink, 2003). The AWPM programme was established in a 15-block area of the New Orleans French Quarter with the homeowners, in the USDA-ARS campus and in southern Mississippi. The programme seems to be successful so far, and work continues to help provide long-term sustainable population control.

Several other AWPM projects, which will be covered in the case examples, include salt cedar (Tamarix ramosissima) in the western USA (ARS), rice insects and grain and vegetable crops in South-east Asia and grape AWPM in Italy. Other authors elsewhere have recently described areawide control or eradication efforts (Vreysen et al., 2007), including the red palm weevil of coconut, the mosquito Aedes albopictus in Italy, mosquito control in Greece, painted apple moth in New Zealand, codling moth in British Columbia, Canada and Brazil, Amblyomma in the Caribbean, fruit fly in Central America, Chile, Tunisia and Sudan, mountain pine beetle in Western North America, cotton bollworm in China, tsetse fly in South Africa and Ethiopia, cactus moth in North America (including Mexico), the false codling moth in South Africa, rice stemborers in China, cotton insects in Tajikistan as well as other AWPM-related efforts.

Other potential candidate pests have been suggested, particularly during lively discussions among USDA agencies and their partners over the past decade or so. As the ARS National Program Leader assigned primary responsibility for the agency's AWPM programme initiative, the author of this introductory chapter has been privy to the many discussions and recommendations. Some of these candidates have included insects such as heliothine moths, soybean aphid, Colorado potato beetle, Asian long-horned beetle, emerald ash borer, pink hibiscus mealy bug, glassy-winged sharpshooter, European corn borer, diamondback moth, beet armyworm, cabbage looper, fall armyworm, sugarcane borer, cattle grubs and horn flies; weeds such as water hyacinth, hydrilla, Eurasian water milfoil, Old World climbing fern, German ivy, tropical and aquatic soda apple, kudzu, giant reed, hawkweeds, purple loosestrife, witch weed, knapweed, Scotch thistle, yellow star thistle, jointed goat grass, sickle pod and Salvinia; and pathogens/nematodes such as golden nematode, Chrysanthemum white rust, soybean cyst nematode, citrus bacterial canker, sugarcane leaf scald disease, cereal rusts, dogwood rust, late blight of potatoes, wheat scab, early blight of tomatoes and Pierce's disease of grapes (glassy-winged sharpshooter).

Not all of the pests suggested will necessarily be good candidates for AWPM/ total population management, and may not fit well with the AWPM criteria, especially species that appear so sporadically that AWPM would not be justified. Some of the potential candidates mentioned are already apparently under some level of biocontrol or IPM practices. The list, of course, is probably not all-inclusive by any means.

Based on the increasing number of AWPM projects being implemented, the recent resurgence of interest in the AWPM concept and how well current practising end-users seem to have embraced the idea, the future looks good for its continued, and even accelerated, adoption and use. Organized coordination and cooperation must continue to be sought, if AWPM programmes of regional and broader geographic scope shall succeed. It is hoped that this book will contribute to the interest in AWPM and its importance to pest managers, as well as to a further understanding of what the concept has to offer. 


\section{References}

Abel, C.A., Snodgrass, G.L. and Gore, J. (2007) A cultural method for the areawide control of tarnished plant bug in cotton. In: Vreysen, M.J., Robinson, A.S. and Hendrichs, J. (eds) Area-Wide Control of Insect Pests: from Research to Field Implementation, Springer, Dordrecht, The Netherlands (in press).

Anderson, G.L. Prosser, C.W., Wendel, L.E., Delfosse, E.S. and Faust, R.M. (2003) The ecological areawide management (TEAM) of leafy spurge program of the United States Department of Agriculture-Agricultural Research Service. Pest Management Science 59, 609-613.

APHIS (Animal \& Plant Health Inspection Service) (2003) Gypsy Moth: Slow the Spread Program. Fact sheet, plant protection and quarantine, April 2003, USDA-APHIS, Riverdale, Maryland, 3 pp.

Bajwa, W.I. and Kogan, M. (2002) Compendium of IPM Definitions (CID) - what is IPM and How is it Defined in the Worldwide Literature? IPPC Publication No. 998, Integrated Plant Protection Center (IPPG), Oregon State University, Corvallis, Oregon, 15 pp.

Baumhover, A.H. (2002) A personal account of programs to eradicate the screw worm, Cochliomyia hominivorax, in the United States and Mexico with special emphasis on the Florida program. Florida Entomologist 85, 669-676.

Bellows, T.S. (1987) Regional management strategies in stochastic systems. Bulletin of the Entomological Society of America 33, 151-154.

Benbrook, C.M., Groth, E., Halloran, J.M., Hansen, M.K. and Marquardt, S. (1996) Pest Management at the Crossroads. Consumers Union, Yonkers, New York, 272 pp.

Bushland, R.C. (1985) Eradication program in the southwestern United States. Miscellaneous Publications of the Entomological Society of America 62, 12-15.

Calkins, C.O. and Faust, R.M. (2003) Overview of areawide programs and the program for suppression of codling moth in the western USA directed by the United States Department of Agriculture - Agricultural Research Service. Pest Management Science 59, 601-604.

Chandler, L.D. (2003) Corn rootworm areawide management program: United States Department of Agriculture - Agricultural Research Service. Pest Management Science 59, 605-608.

Chandler, L.D. and Faust, R.M. (1998) Overview of areawide management. Foumal of Agricultural Entomology 15, 319-325.

Cole, T.W. and MacKeller, W.M. (1956) Cattle tick fever. In: Animal Diseases. US Department of Agriculture Yearbook 1956, Washington, DG, pp. 310-313.

De Quattro, J. (1997) The whitefly plan - 5 year update. Agricultural Research 45, 4-12.

Dickerson, W.A. and Haney, P.B. (200l) A review and discussion of regulatory issues. In: Dickerson, W.A., Brashear, A.L., Brumley, J.T., Carter, F.L. and Grefenstette, W.J. (eds) Boll Weevil Eradication in the United States Through 1999. The Cotton Foundation Publisher, Memphis, Tennessee, pp. 137-156.

Doutt, R.L. (1958) Vice, virtue and the vedalia. Bulletin of the Entomological Society of America 4, 1 19-123.

Faust, R.M. and Chandler, L.D. (1998) Future programs in areawide pest management. Foumal of Agricultural Entomology 15, 371-376.

Flinn, P.W., Hagstrum, D.W., Reed, C. and Phillips, T.W. (2003) United States Department of Agriculture - Agricultural Research Service stored-grain areawide integrated pest management program. Pest Management Science 59, 614-618.

Flores, A. (2004a) TAMEing Melaleuca with IPM. Agricultural Research 52, 48.

Flores, A. (2004b) Tick control methods head to Scotland. Agricultural Research 52, 21.

Flores, A. (2006) The continuing fight against cattle ticks. Agricultural Research 54, 8-9. 
Flores, A. and Core, J. (2004) Putting out the fire: ARS sets up regional programs to combat imported fire ants. Agricultural Research 52, 12-13.

Hendrichs, J. and Ortiz, G. (1996) Fruit fly (Diptera: Tephritidae) area-wide integrated management programmes in progress in the world. Paper \#22- 025, abstract in Proceedings $X X$ Intermational Congress of Entomology, Florence, Italy. p. 705.

Henneberry, T.J. and Phillips, J.R. (1996) Suppression and management of cotton insect populations on an areawide basis. In: King, E.G., Phillips, J.R. and Coleman, R.J. (eds) Cotton Insects and Mites: Characterization and Management. The Cotton Foundation Publisher, Memphis, Tennessee, pp. 601-624.

Henneberry, T.J., Faust, R.M., Jones, W.A. and Perring, T.M. (2002) Silverleaf Whitefly: National Research, Action and Technology Transfer Plan (formerly Sweetpotato Whitefly, Strain B): Fourth Annual Review of the Second 5-year Plan and Final Report for 1992-2002, held in San Diego, California, February 10-12, 2002. US Department of Agriculture, Agricultural Research Service, June 2002, 446 pp.

Keenan, S.P., Giles, K.L., Elliott, N.G., Royer, T.A., Porter, D.R., Burgener, P.A. and Christian, D.A. (2007) Grower perspectives on areawide wheat integrated pest management in the southern US Great Plains. In: Koul, O. and Cuperus, G.W. (eds) Ecological Based Integrated Pest Management. CAB International, Wallingford, UK, pp. 289-314.

Klassen, W. (2003) Memorial lecture - Edward F. Knipling: titan and driving force in ecologically selective area-wide pest management. Joumal of the American Mosquito Control Association 19, 94-103.

Knipling, E.F. (1966) Some basic principles in insect population suppression. Bulletin of the Entomological Society of America 12, 7-15.

Knipling, E.F. (1978) Eradication of plant pests - pro-advances in technology for insect population eradication and suppression. Bulletin of the Entomological Society of America 24, 44-52.

Knipling, E.F. (1979) The Basic Principles of Insect Population Suppression and Management. US Department of Agriculture, Agriculture Handbook no. 512, Washington, DC, 659 pp.

Knipling, E.F. (1980) Regional management of the fall armyworm - a realistic approach. Florida Entomologist 63, 468-480.

Knipling, E.F. and Stadelbacker, E.A. (1983) The rationale for areawide management of Heliothis (Lepidoptera: Noctuidae) populations. Bulletin of the Entomological Society of America 29, 29-37.

Kogan, M. (1982) Plant resistance in pest management. In: Metcalf, R. and Luckman, H. (eds) Introduction to Insect Pest Management, 2nd edition. Wiley, New York, pp. 93-134.

Kogan, M. (1995) Areawide management of major pests: is the concept applicable to the Bemisia complex? In: Gerling, D. and Mayer, R.T. (eds) Bemisia: Taxonomy, Biology, Damage, Control and Management 1995. Intercept, Andover, UK, pp. 643-657.

Lax, A.R. and Osbrink, W. (2003) United States Department of Agriculture - Agriculture Research Service research on targeted management of the Formosan subterranean termite Coptotermes formosanus Skiroki (Isoptera: Rhinotermitidae). Pest Management Science $59,788-800$.

Mau, R.F., Jang, E.B. and Vargas, R.I. (2007) The Hawaii area-wide fruit fly pest management programme: influence of partnership and a good education programme. In: Vreysen, M.J., Robinson, A.S. and Hendrichs, J. (eds) Area-Wide Control of Insect Pests: from Research to Field Implementation. Springer, Dordrecht, The Netherlands (in press).

McGraw, L. and McBride, J. (2001) Tick control device reduces lyme disease. Agricultural Research, 49, 5-7.

Myers, J.H., Savoie, A. and Randen, E. (1998) Eradication and pest management. Annual Reviews of Entomology 43, 471-491.

Pereira, R.M. (2004) Area-wide suppression of fire ant populations in pastures: project update. Joumal of Agricultural Urban Entomology 20, 123-130. 
Pound, J.M., Miller, J.A., George, J.E. and Le Meilleur, C.A. (2000a) The '4-poster' passive topical treatment device to apply acaricide for controlling ticks (Acari: Ixodidae) feeding on white-tailed deer. Joumal of Medical Entomology 37, 585-594.

Pound, J.M., Miller, J.A. and George, J.E. (2000b) Efficacy of amitraz applied to white-tailed deer by the '4-poster' topical treatment device in controlling free-living lone star ticks (Acari: Ixodidae). Joumal of Medical Entomology 37, 878-884.

Rabb, R.L. (1978) A sharp focus on insect populations and pest management from a wide-area view. Bulletin of the Entomological Society of America 24, 55-61.

Schneider, S.M., Rosskodf, E.N., Leesch, J.G., Chellemi, D.O., Bull, C.T. and Mazzola, M. (2003) United States Department of Agriculture-Agricultural Research Service research on alternatives to methyl bromide: pre-plant and post-harvest. Pest Management Science 59, 814-826.

Scoles, J.G., Pratt, P.D., Silvers, C.S., Langeland, K.A., Meisenburg, M.J., Ferriter, A.P., Gioeli, K.T. and Gray, C.J. (2006) The Land Manager's Handbook on Integrated Pest Management of Melaleuca quinquenervia. USDA-ARS, Fort Lauderdale, Florida, $55 \mathrm{pp}$.

Stall, W.M. (1999) IPM definition. Foumal of Vegetable Crop Production, 4, 95-96.

USDA-APHIS (United States Department of Agriculture-Animal Plant Health Inspection Service) (1998) Eradicating screw worms from North America. APHIS Web site (http:// www.aphis.usda.gov/OA/Screw worm.html).

USDA-ARS-APHIS-U.WY (United States Department of Agriculture-Agriculture Research Service-Animal and Plant Health Inspection Service-University of Wyoming) (2001) Grasshoppers: their biology, identification and management. In: Branson, D. and Redlin, B. (eds) (CD, June 2001). USDA-ARS, Sidney, Montana.

Van der Meer, R.K., Porter, S.D., Oi, D.H., Valles, S.M. and Pereira, R.M. (2007) Area-wide suppression of invasive fire ant populations. In: Vreysen, M.J., Robinson, A.S. and Hendrichs, J. (eds) Area-Wide Control of Insect Pests: from Research to Field Implementation. Springer, Dordrecht, The Netherlands (in press).

Vreysen, M.J.B., Saleh, K.M., Ali, M.Y., Abdulla, A.M., Zhu, Z.R., Juma, K.G., Dyck, A.V., Msangi, A.R., Mkonyi, P.A. and Feldmann, H.V. (2000) Glossina austeni (Diptera: Glossinidae) eradicated on the island of Unguja, Zanzibar, using the sterile insect technique. Joumal of Economic Entomology 93, 123-135.

Vreysen, M.J., Robinson, A.S. and Hendrichs, J. (2007) Area-wide Control of Insect Pests: from Research to Field Implementation, Springer, Dordrecht, The Netherlands (in press).

Weaver-Missick, T. (1999) Banishing tarnished plant bugs from cotton, Agricultural Research 47, $12-14$. 